only for small temperature-excesses, and the effect of temperature on the velocity of sound is given in the form $v=v_{0}\left(1+\frac{1}{2} \alpha t\right)$. It is more correct, twice as clear, and half as long, to show in a couple of lines that the velocity is proportional to the square root of the absolute temperature.

These minor errors will doubtless be corrected in a second edition.

A. F.

\section{Tropical Aquariums, Plants and Fishes}

By A. Laurence Wells. Pp. 160. (London and New York : Frederick Warne and Co., Ltd., 1937.) 3s. $6 d$. net.

THIS is a very useful little book written in a popular style by an expert in keeping and rearing small tropical fishes. Mr. Wells has already published valuable guides dealing with similar subjects : aquariums and fish ponds, and garden ponds, fish and fountains. The present book will be welcomed by many, for the cult of the tiny tropical fish is rapidly increasing, and a sound practical book, simply written, is exactly what is needed, and this is what is offered. With its aid there should be no difficulty in setting up aquaria and rearing the fishes. The aquarium itself, heating, feeding, the best plants to use and how to deal with ailments, all have their share of space, but half the book is taken up with short descriptions of the various fishes themselves, their distribution, habits, the prices which they fetch and information for the treatment of each species. The book is illustrated by numerous small sketches, nearly every fish being figured and also the various plants recommended for living in the aquarium.

It might be pointed out that in describing the food certain terms are used which are rather unusual: for example, algæ as a singular noun and Daphnoe and Enchytrce as plurals.

\section{The Alloys of Iron and Chromium}

Vol. 1: Low-Chromium Alloys. By A. B. Kinzel and Walter Crafts. (Alloys of Iron Research, Monograph Series.) Pp. xv +535. (New York and London : McGraw-Hill Book Co., Inc., 1937.) $36 s$.

$\mathrm{T}$ HIS volume is the first part of a review and summary of published information and available unpublished data on the alloys of iron and chromium containing less than 10 per cent of chromium. The second part, now in preparation, will deal with higher chromium alloys, including the heat- and corrosion-resisting steels. The constitution of the iron - chromium and the iron - carbon chromium systems and the effect of chromium on the critical point is first dealt with, these chapters being followed by surveys of the manufacture, treatment and properties of chromium steels and cast irons. In preparing this monograph it is stated that nine thousand papers and articles were assembled, and that of these $\mathbf{4 7 8}$ were selected for detailed study. The latter group is given as a bibliography, arranged chronologically, and will prove a very valuable feature of the book. A great wealth of data has been assembled in this volume, both in the text and in a large number of excellent tables and diagrams.
Metallography

By Dr. Cecil H. Desch. Fourth edition. Pp. viii + $402+17$ plates. London, New York and Toronto : Longmans, Green and Co., Ltd., 1937.) 21s. net.

GOR twenty-eight years, Dr. Cecil Desch's "Metallography" has served admirably as a standard text-book for students of physical metallurgy, and had previously run through three editions. The last of these, however, goes back to 1922, and therefore a new and revised edition was considered desirable. This has involved the re-writing of most of the book as well as the introduction of new topics; among the latter are the improved technique of thermal analysis and of microscopic examination, the changes occurring in solid alloys (including age-hardening and the orderdisorder transformation) and the processes of mechanical deformation. A section dealing with developments on the X-ray side has been contributed by G. D. Preston.

With the passing of time since this book was first published, it has become still more hopeless a task to compress into one volume our knowledge of physical metallurgy; but as an introduction and as a guide to the literature it continues to fulfil its function very well.

\section{An Introduction to Abnormal Psychology}

By V. E. Fisher. Revised edition. Pp. xiii +533. (New York: The Macmillan Co., 1937.) 12s. 6d. net.

7 HIS book appears in a thoroughly revised form. 1 The lapse of only a few years necessitates much revision in an exposition of such a subject as abnormal psychology. But the author has done more than amend the first edition. He has added seven new chapters and omitted three of the old ones, doubled the number of illustrative cases, and otherwise introduced a good deal of fresh material.

The book is essentially a text-book, giving full directions for further reading, and aiming at a thoroughly comprehensive view of the whole subject. At the same time, it is interestingly written, and merits the attention of the general reader as well as that of the student of psychology.

\section{The Basis of Tissue Evolution and Pathogenesis}

By Dr. Albert A. Gray. Pp. xix $+92+7$ plates. (Glasgow : Jackson, Son and Co., 1937.) 7s. 6d. net.

TN this book, which is the posthumous work of an I eminent Glasgow otologist, the author maintains that all tissues ultimately arise as the result of repair following injury, and supports his contention by examples of the labyrinth in animals taken from his work on the subject. He points out that the term 'injury' does not mean merely gross mechanical injury but also includes the damage inflicted by chemical agents, poisons and physical conditions, such as moisture, heat, cold, etc. He does not, however, exclude the possibility of chance variations or mutations having also played a part in the process of evolution.

A short sketch of Dr. Gray's life and work is given in the foreword by his son. 